\title{
Invitro Evaluation of Herbs Containing Essential Oils Supplementation on Methane Production and Nutrient Digestibility of Total Mixed Rations
}

\author{
Vivek Sharma, J.S. Lamba ${ }^{*}$, R.S. Grewal and J.S. Hundal \\ Department of Animal Nutrition, College of Veterinary Sciences, Guru Angad Dev Veterinary \\ and Animal Sciences University, Ludhiana, Punjab, India \\ *Corresponding author
}

\section{A B S T R A C T}

\section{Key words \\ In vitro gas production, Herbs, Methane production \\ Article Info \\ Accepted: \\ 04 March 2018 \\ Available Online: \\ 10 April 2018}

The study was taken up to assess the effect of herbs containing essential oils (EOs) viz. Jaiphal, Suva and Haldi supplemented individually at 1 to $3 \%$ levels on TMR varying in different $\mathrm{R}: \mathrm{C}$ on the in vitro methane production and utilization of nutrients. Supplementation of jaiphal, irrespective of their level had significantly $(\mathrm{P}<0.05)$ higher OMD \%, PF (partition factor), NDFD, DMD, The methane production on DMD and OMD basis, A/P ratio was lowest $(\mathrm{P}<0.05)$ in jaiphal supplemented TMR but it was comparable in other supplemented TMRs. Irrespective of the of herb and $\mathrm{R}: \mathrm{C}$ ratio, the PF, OMD\%, NDFD\%, MMP and EMMP and DM digestibility was significantly $(\mathrm{P}<0.05)$ higher at $1 \%$ level of herb supplementation in TMRs. It was concluded that jaiphal supplementation @ $1 \%$ level significantly $(\mathrm{P}<0.05)$ reduced the methane production and improved the utilization of nutrients.

\section{Introduction}

Recently, there have been growing concerns over greenhouse gas emissions because of their effects on global warming and climate change, and consequently on the regional as well as global ecological and socio-economic vulnerability (IPCC, 2007). Methane is one of the greenhouse gasses, which is normally produced during the anaerobic enteric fermentation of feeds in many animals including ruminants. Methane has 21 times more global warming potential than carbon dioxide (IPCC, 2007). It is estimated that the world's population of ruminants produces about $15 \%$ of total methane emissions (Moss et al., 2000). Besides, methane produced in ruminants represents a substantial loss of 2$15 \%$ of gross energy intake which reduces the potential conversion of feed energy to metabolizable energy. Hence, the inhibition of methanogenesis has long been considered from nutritional aspects, and more recently from the perspectives on greenhouse gas emissions. Many chemical feed additives were tried to decrease methane production in the rumen. However, these chemical additives are either toxic to host animals or have a transient effect on methanogenesis (Moss et al., 2000). In addition, an increasing awareness of hazards associated with chemical feed additives, i.e. presence of chemical residues in animal derived foods and development of bacterial resistance to antibiotics has diverted 
the research on feed additive technology towards exploiting natural products as feed additives. Antibiotics and other synthetic additives used in animal feeding have been effectively banned by the European Union since 2006 (regulation 1831/2003/EC). Plants produce a diverse array of plant secondary metabolites (PSM) to protect against microbial and insects attacks. These natural plant eco chemicals such as essential oils (EOs), saponins, tannins and organosulphur compounds have been shown to selectively modulate the rumen microbial populations (Patra and Saxena, 2009) resulting in an improvement of rumen fermentation and nitrogen metabolism, and a decrease in methane production and thus improving the productivity and health of animals. Essential oils are seen as a potential alternative to antibiotic drugs and additives in both animal and human diets because they have antimicrobial properties against a wide variety of microorganisms (Benchaar et al., 2008). Nutritionists and rumen microbiologists have therefore recently shown great interest in exploiting EO as natural feed additives for the purpose of improving rumen fermentation through volatile fatty acid production, inhibition of methanogenesis, improving protein metabolism and increasing the efficiency of feed utilization. Hence this study was being planned to see the effect of different herbs containing essential oils varying levels of herbs supplementation on in vitro utilization and methane production potential from different herbs in total mixed rations (TMR) varying in Roughage to concentrate ratio by in vitro gas production technique.

\section{Materials and Methods}

\section{Animal feeding and sample analysis}

The TMRs were formulated with roughage to concentrate ratio of 80:20, 75:25, 70:30 and 65:35 on DM basis. The roughage portion was made up of wheat straw and maize green fodder in 70:30 ratio, while concentrate mixture was prepared of maize 15 , wheat 15 , deoiled mustard cake 15, mustard cake 10, soybean meal 10 , rice bran 15 , deoiled rice bran 16 , urea 1 , salt 1 , mineral mixture $2 \%$. The different ratios TMRs were supplemented with herbs (Jaiphal, Suva and Haldi) @1 to $3 \%$ in order to find out the optimum level by using in vitro gas production technique. Rumenliquor was collected in the morning from fistulated animals before feeding and watering into a pre-warmed thermo-flask and brought to the laboratory. Donor animals were fed on basal diet (concentrate @ $3 \mathrm{~kg}$ and wheat straw ad libitum). The in vitro gas production was done according to Menke et al., (1979).The amount of net gas produced (NGP) was used to calculate the metabolizable energy (ME) value. Neutral detergent fibre (NDF) of the residue was also determined. Total degradable sample (TDS), organic matter degradability (OMD), partition factor (PF), \% organic matter degradability (\% OMD), \% neutral detergent fibre degradability (\% NDFD), microbial biomass production (MBP), efficiency of microbial mass production (EMMP), true digestibility (TD) and short chain fatty acids (SCFA) were calculated according to formulae suggested by Makkar (2004). Volatile fatty acids (VFAs) were estimated by Cottoyn and Boucque (1968) using gas liquid chromatography (GLC) technique using Net Chrom-9100 model. The gas column (6 ft length and 1/8 inch diameter) packed with chromosorb101 was used for the estimation of VFA. The gas flows for nitrogen hydrogen and zero air were 30,30 , and $320 \mathrm{ml} / \mathrm{min}$, respectively. Temperature of injector oven, column even and detector were $270^{\circ} \mathrm{C}, 172^{\circ} \mathrm{C}$ respectively.

\section{Statistical analysis}

Data found from in-vitro study were analyzed $4 \times 3 \times 3$ factorial design (Snedecor and Cochran, 
1994), by using SPSS Version 19. The differences in means were tested by Tukey B.

\section{Results and Discussion}

The chemical composition of TMRs vatrying in roughage to concentrate ratios prepared for in vitro studies (Table 1) revealed that $\mathrm{CP}$ content varied from 11.2 to 13.26 percent. With increase in the level of concentrate in TMRs, the organic matter, ether extract, and crude protein content increased, while acid detergent fiber, cellulose and neutral detergent fiber content decreased as expected.

The effect of supplementing herbs on digestibility of nutrients revealed that NGP $(\mathrm{ml} / 24 \mathrm{~h} / \mathrm{g}$ DM) varied $(\mathrm{P}<0.05)$ from 180.42 in control and highest in suva supplemented TMR to 188.74, irrespective of R: C and level of herb supplementation (Table 2).

The digestibility of nutrients (DM, OM, and $\mathrm{NDF})$ of varied significantly $(\mathrm{P}<0.05)$ amongst the herbs supplemented. Supplementation of TMR with jaiphal showed higher $(\mathrm{P}<0.05)$ digestibility of dry matter organic matter and neutral detergent fibre, followed by suva and haldi. The digestibility of nutrients for DM, OM and NDF was significantly lower in control TMR (no Herb supplementation).

The Partitioning Factor (PF), i.e. the ratio of substrate truly degraded to the volume of gas produced was comparable in control and jaiphal supplementation in TMR and varied significantly $(\mathrm{P}<0.05)$ from 3.39 (control) to 3.34 (jaiphal) indicating proportionally more of the degraded matter will be incorporated in microbial mass. However, the PF was significantly lower in suva and haldi supplementation TMRs. Microbial mass production was statistically comparable in control and jaiphal supplemented TMRs but the efficiency of microbial mass production was significantly lower in herbs supplemented TMRs. Metabolizable energy (ME) MJ/kgDM was significantly lower (8.25) in control TMR, but statistically comparable in all herbs supplemented TMRs. The short chain fatty acids (SCFA) was lower $(\mathrm{p}<0.05)$ in control total mixed ration $(0.86 \mathrm{mmole})$ and was comparable in all herbs supplemented TMRs. It varied from $0.89 \mathrm{~m}$ mole to $0.905 \mathrm{~mm}$ mole in herbs supplemented TMRs. The concentration of ammonia was lower $(p<0.05)$ in jaiphal supplemented total mixed ration (20.68mg/dl) and highest in haldi TMR (20.96 $\mathrm{mg} / \mathrm{dl})$.

The amount of fermentable methane (1.44 mmol) and fermentable carbon dioxide $(2.47 \mathrm{mmol})$ was lower $(\mathrm{p}<0.05)$ in control TMR where as both these were higher $(p<0.05)$ in haldi based TMR.

The values for total volatile fatty acid concentration obtained in this study varied $(\mathrm{P}<0.05)$ from $5.45 \mathrm{mM} / \mathrm{dl}$ (control) to 6.31 $\mathrm{mM} / \mathrm{dl}$ (haldi). The acetate, propionate, isobutyrate and butryrate levels followed the same trend as that in TVFAs (Table 3). The A: $P$ ratio was observed to be low in TMR supplemented with jaiphal (2.30) and highest in haldi supplemented TMR (2.55) irrespective of $\mathrm{R}$ : $\mathrm{C}$ and levels of supplementation, indicating shift towards propionate.

The methane as percent of net gas production, irrespective of R: C and level of herb supplementation is shown in the (Table 4) It was significantly $(\mathrm{p}<0.05)$ lower in jaiphal supplemented TMR $(20.42 \%)$ and statistically comparable in all other herbs supplemented TMRs. Methane production $\mathrm{ml} /$ 100mg DMD and organic matter basis was significantly $(\mathrm{p}<0.05)$ lower in jaiphal supplemented TMR $(5.38$ and $6.07 \mathrm{ml})$ However, it was comparable in control and all other herbs supplemented TMR. 
Table.1 Chemical composition of TMRs varying in R: C ratios

\begin{tabular}{|c|c|c|c|c|}
\hline \multirow{2}{*}{ Parameters } & \multicolumn{4}{|c|}{ Roughage: Concentrate ratio } \\
\hline CP & $\mathbf{8 0 : 2 0}$ & $\mathbf{7 5 : 2 5}$ & $\mathbf{7 0 : 3 0}$ & $\mathbf{6 5 : 3 5}$ \\
\hline ASH & 11.2 & 11.65 & 11.97 & 13.26 \\
\hline OM & 10.25 & 9.65 & 9.65 & 9.55 \\
\hline NDF & 89.75 & 90.35 & 90.35 & 90.45 \\
\hline ADF & 70.0 & 69.10 & 68.2 & 64.0 \\
\hline HC & 45.80 & 43.40 & 42.20 & 38.40 \\
\hline FAT & 24.20 & 25.70 & 26.00 & 25.60 \\
\hline Cellulose & 1.43 & 1.63 & 1.76 & 1.80 \\
\hline & 37.2 & 35.40 & 31.30 & 29.80 \\
\hline
\end{tabular}

Table.2 Effect of different herbs containing essential oils on in-vitro utilization of nutrients of different TMRs at 24h, irrespective of R: C and level of herb

\begin{tabular}{|c|c|c|c|c|c|}
\hline \multirow[t]{2}{*}{ Parameters } & \multicolumn{4}{|c|}{ Herbs used } & \multirow[t]{2}{*}{ SEM } \\
\hline & Control & Jaiphal & Suva & Haldi & \\
\hline NGP, ml/gDM & $180.42 \mathrm{a}$ & $186.94 b$ & $188.74 d$ & $186.67 \mathrm{~b}$ & 1.04 \\
\hline OMD, mg/gDM & $612.26 a$ & $625.61 b$ & $619.25 \mathrm{ab}$ & $618.16 a b$ & 3.80 \\
\hline PF & $3.39^{\mathrm{b}}$ & $3.34^{\mathrm{b}}$ & $3.28^{\mathrm{a}}$ & $3.31^{\mathrm{a}}$ & 0.13 \\
\hline OMD, \% & $67.85^{\mathrm{a}}$ & $69.33^{\mathrm{b}}$ & $68.62^{\mathrm{ab}}$ & $68.503^{\mathrm{ab}}$ & 0.40 \\
\hline NDFD, $\%$ & $57.92^{\mathrm{a}}$ & $59.85^{\mathrm{b}}$ & $58.94^{\mathrm{ab}}$ & $58.78^{\mathrm{ab}}$ & 0.47 \\
\hline MMP, mg & $81.93 b$ & $80.33 \mathrm{ab}$ & $77.06 \mathrm{a}$ & $77.99 a$ & 1.44 \\
\hline EMMP,\% & $35.62 b$ & $34.28 \mathrm{a}$ & $33.12 \mathrm{a}$ & $33.47 \mathrm{a}$ & 0.47 \\
\hline TD, \% & $68.800^{\mathrm{a}}$ & $70.595^{b}$ & $69.906^{\mathrm{ab}}$ & $69.6^{b}$ & 0.39 \\
\hline SCFA, m mole & $0.869^{\mathrm{a}}$ & $0.895^{\mathrm{b}}$ & $0.905^{\mathrm{b}}$ & $0.900^{\mathrm{b}}$ & 0.005 \\
\hline ME, MJ/kg DM & $8.255^{\mathrm{a}}$ & $8.408^{\mathrm{b}}$ & $8.477^{\mathrm{b}}$ & $8.446^{\mathrm{b}}$ & 0.043 \\
\hline $\mathrm{NH}_{3}-\mathrm{N}$ mg/dl & $21.09^{d}$ & $20.68^{\mathrm{a}}$ & $20.91^{b}$ & $20.96^{\mathrm{c}}$ & 0.11 \\
\hline Ferm. $\mathrm{CO}_{2}, \mathrm{mmol}$ & $2.72 \mathrm{a}$ & $3.07 \mathrm{c}$ & $2.96 \mathrm{~b}$ & $3.14 d$ & 0.050 \\
\hline Ferm. $\mathrm{CH}_{4}, \mathrm{mmol}$ & $1.57 \mathrm{a}$ & $1.75 \mathrm{c}$ & $1.71 \mathrm{~b}$ & $1.80 \mathrm{~d}$ & 0.027 \\
\hline
\end{tabular}

Means bearing different superscripts in a row differ significantly $(\mathrm{P}<0.05)$ 
Table.3 Effect of herbs containing essential oils on in-vitro volatile fatty acids production $(\mathrm{mM} / \mathrm{dl})$ of different TMRs at 24h, irrespective of R: C and level of supplementation

\begin{tabular}{|c|c|c|c|c|c|}
\hline \multirow[t]{2}{*}{ Parameters } & \multicolumn{4}{|c|}{ Herbs Used } & \multirow[t]{2}{*}{ SEM } \\
\hline & Control & Jaiphal & Suva & Haldi & \\
\hline Acetic acid & $3.453^{\mathrm{a}}$ & $3.872^{c}$ & $3.771^{b}$ & $3.979^{\mathrm{d}}$ & 0.066 \\
\hline Propionic acid & $1.455^{\mathrm{a}}$ & $1.695^{\mathrm{c}}$ & $1.622^{b}$ & $1.712^{\mathrm{d}}$ & 0.036 \\
\hline Iso butyric acid & $0.024^{\mathrm{a}}$ & $0.029^{c}$ & $0.028^{b}$ & $0.030^{\mathrm{d}}$ & 0.0007 \\
\hline Butyric acid & $0.423^{\mathrm{a}}$ & $0.478^{c}$ & $0.452^{b}$ & $0.481^{\mathrm{d}}$ & 0.007 \\
\hline Isovaleric acid & $0.055^{\mathrm{a}}$ & $0.062^{\mathrm{d}}$ & $0.058^{\mathrm{b}}$ & $0.062^{c}$ & 0.001 \\
\hline Valeric acid & $0.042^{\mathrm{a}}$ & $0.047^{\mathrm{d}}$ & $0.044^{b}$ & $0.046^{\mathrm{c}}$ & 0.0007 \\
\hline TVFA & $5.452^{\mathrm{a}}$ & $6.184^{c}$ & $5.975^{b}$ & $6.309^{d}$ & 0.11 \\
\hline A/P Ratio & $2.396^{\mathrm{ab}}$ & $2.302^{\mathrm{a}}$ & $2.343^{\mathrm{ab}}$ & $2.555^{\mathrm{b}}$ & 0.037 \\
\hline
\end{tabular}

Means bearing different superscripts in a row differ significantly $(\mathrm{P}<0.05)$

Table.4 Methane production from fermentation of TMRs, at 24h, irrespective of R: C and level of herb supplementation

\begin{tabular}{l|l|l|l|l|l|} 
Parameters & \multicolumn{3}{c}{ Herbs Used } & SEM \\
\hline & Control & Jaiphal & Suva & Haldi & \\
\hline CH4\% & $21.55^{\mathrm{b}}$ & $20.42^{\mathrm{a}}$ & $21.14^{\mathrm{b}}$ & $21.25^{\mathrm{b}}$ & 0.37 \\
\hline CH4ml/gDM & $38.68^{\mathrm{a}}$ & $38.10^{\mathrm{a}}$ & $39.80^{\mathrm{b}}$ & $39.71^{\mathrm{b}}$ & 0.58 \\
\hline CH4ml/100mgDMD & $5.60^{\mathrm{b}}$ & $5.38^{\mathrm{a}}$ & $5.68^{\mathrm{b}}$ & $5.68^{\mathrm{b}}$ & 0.065 \\
\hline CH4ml/100mgOMD & $6.29^{\mathrm{b}}$ & $6.07^{\mathrm{a}}$ & $6.42^{\mathrm{b}}$ & $6.40^{\mathrm{b}}$ & 0.071
\end{tabular}

Means bearing different superscripts in a row differ significantly $(\mathrm{P}<0.05)$

Table.5 Effect of different levels of herbs supplementation on in vitro utilization of nutrients at $24 \mathrm{hr}$, irrespective of R: C and herb

\begin{tabular}{|l|l|l|l|l|l|}
\hline Parameters & \multicolumn{3}{|c|}{ Levels of herbs supplementation } & SEM \\
\hline NGP/gDM & Control & $\mathbf{1 \%}$ & $\mathbf{2 \%}$ & $\mathbf{3 \%}$ & \\
\hline OMD, mg/gDM & $180.42^{\mathrm{a}}$ & $186.46^{\mathrm{b}}$ & $189.82^{\mathrm{c}}$ & $190.93^{\mathrm{c}}$ & 1.04 \\
\hline PF & $612.26^{\mathrm{a}}$ & $626.26^{\mathrm{b}}$ & $616.45^{\mathrm{a}}$ & $624.61^{\mathrm{b}}$ & 3.80 \\
\hline OMD, \% & $3.39^{\mathrm{c}}$ & $3.35^{\mathrm{c}}$ & $3.24^{\mathrm{a}}$ & $3.27^{\mathrm{b}}$ & 0.126 \\
\hline NDFD, \% & $67.851^{\mathrm{a}}$ & $69.402^{\mathrm{b}}$ & $68.313^{\mathrm{a}}$ & $69.219^{\mathrm{b}}$ & 0.40 \\
\hline MMP, mg & $57.925^{\mathrm{a}}$ & $59.955^{\mathrm{b}}$ & $58.539^{\mathrm{a}}$ & $59.715^{\mathrm{b}}$ & 0.47 \\
\hline EMMP, \% & $81.93 \mathrm{c}$ & $80.54 \mathrm{c}$ & $74.32 \mathrm{a}$ & $77.61 \mathrm{~b}$ & 1.43 \\
\hline TD, \% & $35.62 \mathrm{c}$ & $34.24 \mathrm{~b}$ & $32.00 \mathrm{a}$ & $33.07 \mathrm{a}$ & 0.47 \\
\hline SCFA, mmole & $68.800^{\mathrm{a}}$ & $70.801^{\mathrm{b}}$ & $69.436^{\mathrm{a}}$ & $70.607^{\mathrm{b}}$ & 0.39 \\
\hline ME, MJ/kg DM & $0.869^{\mathrm{a}}$ & $0.897^{\mathrm{b}}$ & $0.916^{\mathrm{c}}$ & $0.910^{\mathrm{c}}$ & 0.005 \\
\hline NH3-N, mg/dl & $8.255^{\mathrm{a}}$ & $8.422^{\mathrm{b}}$ & $8.541^{\mathrm{c}}$ & $8.506^{\mathrm{c}}$ & 0.043 \\
\hline Ferm.CO & $21.09^{\mathrm{c}}$ & $21.23^{\mathrm{d}}$ & $20.84^{\mathrm{b}}$ & $20.38^{\mathrm{a}}$ & 0.11 \\
\hline Ferm.CHol & $2.72 \mathrm{a}$ & $3.13 \mathrm{c}$ & $3.16 \mathrm{~d}$ & $3.11 \mathrm{~b}$ & 0.050 \\
\hline
\end{tabular}

Means bearing different superscripts in a row differ significantly $(P<0.05)$ 
Table.6 Effect of different levels of herbs supplementation on in vitro volatile production $(\mathrm{mM} / \mathrm{dl})$ at $24 \mathrm{hr}$, irrespective of R: C TMRs and herb

\begin{tabular}{|l|l|l|l|l|l|}
\hline \multirow{2}{*}{ Parameters } & \multicolumn{3}{|c|}{ Levels of herbs supplementation } & SEM \\
\hline & Control & $\mathbf{1 \%}$ & $\mathbf{2 \%}$ & $\mathbf{3 \%}$ & \\
\hline A cetic acid & $3.453^{\mathrm{a}}$ & $3.95^{\mathrm{c}}$ & $4.026^{\mathrm{d}}$ & $3.928^{\mathrm{b}}$ & 0.066 \\
\hline Propionic acid & $1.455^{\mathrm{a}}$ & $1.718^{\mathrm{b}}$ & $1.731^{\mathrm{d}}$ & $1.721^{\mathrm{c}}$ & 0.036 \\
\hline Iso butyric acid & $0.024^{\mathrm{a}}$ & $0.029^{\mathrm{b}}$ & $0.030^{\mathrm{c}}$ & $0.030^{\mathrm{c}}$ & 0.0007 \\
\hline Butyric acid & $0.423^{\mathrm{a}}$ & $0.482^{\mathrm{d}}$ & $0.481^{\mathrm{c}}$ & $0.478^{\mathrm{b}}$ & 0.007 \\
\hline Isovaleric acid & $0.055^{\mathrm{a}}$ & $0.063^{\mathrm{d}}$ & $0.061^{\mathrm{b}}$ & $0.061^{\mathrm{c}}$ & 0.001 \\
\hline Valeric acid & $0.042^{\mathrm{a}}$ & $0.047^{\mathrm{d}}$ & $0.046^{\mathrm{b}}$ & $0.047^{\mathrm{c}}$ & 0.0007 \\
\hline TVFA & $5.452^{\mathrm{a}}$ & $6.29^{\mathrm{c}}$ & $6.375^{\mathrm{d}}$ & $6.265^{\mathrm{b}}$ & 0.11 \\
\hline A:P ratio & $2.396^{\mathrm{a}}$ & $2.321^{\mathrm{a}}$ & $2.610^{\mathrm{b}}$ & $2.304^{\mathrm{a}}$ & 0.037 \\
\hline
\end{tabular}

Means bearing different superscripts in a row differ significantly $(\mathrm{P}<0.05)$

Table.7 Methane production from fermentation of TMRs at different levels of herbs,irrespective of R:C and Herb at $24 \mathrm{hr}$

\section{Parameters}

CH4\%

$\mathrm{CH} 4 \mathrm{ml} / \mathrm{gDM}$

CH4ml/100mgDMD

CH4ml/100mgOMD

\section{Levels of herbs supplementation}

$$
\mathbf{0 \%}
$$

$21.55^{\mathrm{b}}$

$38.87^{\mathrm{a}}$

$5.65 b$

$6.38 \mathrm{~b}$

\section{$1 \%$}

$21.10^{\mathrm{a}}$

$39.34^{\mathrm{b}}$

$5.35 \mathrm{a}$

$6.31 \mathrm{a}$
$2 \%$

$20.75^{\mathrm{a}}$

$39.38^{\mathrm{a}}$

$5.67 \mathrm{~b}$

$6.42 b$
SEM $3 \%$ \begin{tabular}{l|l}
$20.73^{\mathrm{a}}$ & 0.37
\end{tabular} \begin{tabular}{l|l}
$39.57^{\mathrm{b}}$ & 0.58
\end{tabular} \begin{tabular}{l|l}
$5.60 \mathrm{~b} \quad 0.065$ \\
\hline $6.37 \mathrm{~b}$
\end{tabular} \begin{tabular}{l|l}
$6.37 \mathrm{~b} \quad 0.071$
\end{tabular}

Means bearing different superscripts in a row differ significantly $(\mathrm{P}<0.05)$

The effect of different levels of supplementing herbs on digestibility of nutrients revealed that NGP $(\mathrm{ml} / 24 \mathrm{~h} / \mathrm{g} \mathrm{DM})$ varied $(\mathrm{P}<0.05)$ from 180.42 at $0 \%$ and highest at 2 and $3 \%$ of herbs supplemented TMR (190.93), irrespective of R: C and herb supplementation (Table 5). The digestibility of nutrients (DM, OM, and NDF) at $1 \%$ level of supplementation was significantly $(\mathrm{P}<0.05)$ higher. The digestibility data points towards the fact that supplementation of herbs at $1 \%$ level increased the digestibility of all nutrients.

The Partitioning Factor (PF), i.e. the ratio of substrate truly degraded to the volume of gas produced was statistically comparable at $0 \%$ and $1 \%$ level of supplementation of herb and significantly $(\mathrm{P}<0.05)$ lower at $2 \%$ level of supplementation (3.24) indicating proportionally more of the degraded matter will be incorporated in microbial mass. Microbial mass production was statistically comparable at $0 \%$ and $1 \%$ of supplementation but the efficiency of microbial mass production was significantly lower at 2 and 3\% level of supplementation. Metabolizable energy (ME) $\mathrm{MJ} / \mathrm{kgDM}$ was significantly lower (8.25) at $0 \%$ and highest at 2 and $3 \%$ level of supplementation respectively. The short chain fatty acids (SCFA) was lower $(\mathrm{p}<0.05)$ at $0 \%$ and highest at 2 and $3 \%$ level of supplementation. It varied from $0.86 \mathrm{~m}$ mole to $0.916 \mathrm{mmmolein}$ all levels of herbs supplemented TMRs. The concentration of ammonia was lower $(\mathrm{p}<0.05)$ at $3 \%$ level of herb supplementation $(20.38 \mathrm{mg} / \mathrm{dl})$ and 
highest at $1 \%$ of level $(21.23 \mathrm{mg} / \mathrm{dl})$. The amount of fermentable methane $(1.57 \mathrm{mmol})$ and fermentable carbon dioxide $(2.72 \mathrm{mmol})$ was lower $(\mathrm{p}<0.05)$ at $0 \%$ level of supplementation in control TMR where as both these were higher $(\mathrm{p}<0.05)$ at $2 \%$ level of herb supplementation.

The values for total volatile fatty acid concentration obtained in this study varied $(\mathrm{P}<0.05)$ from $5.45 \mathrm{mM} / \mathrm{dl}(0 \%)$ to 6.31 $\mathrm{mM} / \mathrm{dl}(2 \%)$. The acetate, propionate, isobutyrate and butryrate levels followed the same trend as that in TVFAs (Table 6). The A: $P$ ratio was observed to be low at $1 \%$ level of supplementation (2.32) and highest at $2 \%$ level (2.61) irrespective of $\mathrm{R}$ : $\mathrm{C}$ and herb supplementation.

The methane as percent of net gas production, irrespective of $\mathrm{R}$ : $\mathrm{C}$ and level of herb supplementation is shown in the (Table 7) It was significantly $(\mathrm{p}<0.05)$ lower as the level of supplementation increased from 1 to $3 \%$. At $0 \%$ level it was $(21.55 \%)$ whereas it was statistically comparable at all levels of herb supplementation in the TMRs. Methane production $\mathrm{ml} / 100 \mathrm{mg} \mathrm{DMD}$ and organic matter basis was significantly $(\mathrm{p}<0.05)$ lower at $1 \%$ level of herb supplementation in TMR $(5.35$ and $6.31 \mathrm{ml})$ However, it was comparable at 0 and 2 and $3 \%$ level of herb supplementation.

The Supplementation of jaiphal, irrespective of their level had significantly $(\mathrm{P}<0.05)$ higher OMD \%, PF (partition factor), NDFD, and DMD of nutrients. The methane production on DMD and OMD basis and A/P ratio was lowest $(\mathrm{P}<0.05)$ in jaiphal supplemented TMR but it was comparable in other herbs supplemented TMRs. Irrespective of the of herb and $\mathrm{R}: \mathrm{C}$ ratio, the $\mathrm{PF}, \mathrm{OMD} \%$, NDFD\%, MMP, EMMP and DM digestibility was significantly $(\mathrm{P}<0.05)$ higher at $1 \%$ level of herb supplementation in TMRs. It was concluded that jaiphal supplementation@1\% level significantly $(\mathrm{P}<0.05)$ reduced the methane production and improved the utilization of nutrients.

\section{References}

Benchaar, C., Calsamiglia, S., Chaves, A.V., Frase, G.R., Colombatto, D., McAllister, T.A and Beauchemin, K. A. 2008. A review of plant-derived essential oils in ruminant nutrition and production. Animal Feed Science and Technology, 145: 209-228.

Cottyn, B.G., and Boucque, C.V. 1968. Rapid methods for the gas chromatographic determination of volatile acids in rumen fluid. J. Agric. Food Chem., 16: 105107.

IPCC 2007. Summary for policymakers. In: Solomon, S., Qin, D., Manning, M., Chen, Z., Marquis, M., Averyt, K.B., Tignor, M., Miller, H.L. (Eds.), Climate Change 2007: The Physical Science Basis. Contribution of Working Group I to the Fourth Assessment Report of the Intergovernmental Panel on Climate Change. Cambridge University Press, Cambridge, United Kingdom and New York, NY, USA.

Makkar, H.P.S. 2004. Recent advances in the in vitro gas method for evaluation of nutritional quality of feed resources. In: Assessing Quality and Safety of Animal Feeds. FAO Animal Production and Health Series 160. FAO, Rome, pp. 5588

Menke, K.H., Raab, L., Salewski, A., Steingass, H., Fritz, D. and Scheinder, W. 1979. The estimation of the digestibility and metabolizable energy content of ruminant feedstuffs from the gas production when they are incubated with rumen liquor in vitro. J.Agric. Sci.Camb., 92: 217-222. 
Moss, A.R., Jouany, J.P and Newbold, C. J. 2000. Methane production by ruminants: its contribution to global warming. Annals of Zootechnology. 49: 231-235.

Patra, A. K and Saxena, J. 2009. A new perspective on the use of plant secondary metabolites to inhibit methanogenesis in ruminants. Phytochemistry, 71: 1198-1222.

Snedecor, G.W. and Cochran, W.G. 1994. Statistical Methods, 11th Edn. The Iowa State University Press, Ames, IA, p. 267.

\section{How to cite this article:}

Vivek Sharma, J.S. Lamba, R.S. Grewal and Hundal, J.S. 2018. Invitro Evaluation of Herbs Containing Essential Oils Supplementation on Methane Production and Nutrient Digestibility of Total Mixed Rations. Int.J.Curr.Microbiol.App.Sci. 7(04): 309-316.

doi: https://doi.org/10.20546/ijcmas.2018.704.035 